\title{
MITOLOGIA MODERNA E ILUMINAÇÃO PROFANA: UM BREVE PASSEIO PELOS CAMINHOS DO SURREALISMO
}

RESUMO: Esse artigo pretende investigar as relações entre mito e literatura trazidas pelo movimento surrealista, bem como o conceito de iluminação profana, oriundo dos estudos de Walter conceito de iluminação profana, oriundo dos estudos de Walter Benjamin a respeito dessa vanguarda. Para isso pretende-se
abordar algumas criações elaboradas por importantes nomes abordar algumas criações elaboradas por importantes nomes do surrealismo, como é o caso de André Breton e Louis Aragon, por meio de uma leitura que tratará da possibilidade da criação de uma mitologia moderna e da relação disso com a ideia de iluminação profana, em obras como Nadja e $O$ camponês de Paris ambas de 1928, além disso, busca-se tratar do modo como uso dos mitos, ressignificados na modernidade, por meio da aproximação entre arte e vida, permitiria um novo olhar do homem para o seu tempo e para o mundo que o rodeava, o que poderia, em última instância, revelar caminhos que levariam a transformação e ao reencantamento da realidade.

ABSTRACT: This paper aims to investigate the relationship between myth and literature brought by the Surrealist movement and the concept of profane illumination, coming from Walter Benjamin's studies of this vanguard. To this it is intended to approach some creations produced by important surrealism names, such as André Breton and Louis Aragon, by means of a reading will address the possibility of creation of a modern mythology and that relationship with the lighting idea profane, in works such as Nadja and $O$ camponês de Paris, both from 1928 , furthermore it seeks to treat how the use of myths resignified in modernity, through the rapprochement between art and life, would allow a new look of the man for his time and for and life, would allow a new look of the man for his time and for the world around him, which could, in the last instance reveal pathways that would lead the transformation and re-enchantment of reality.

PALAVRAS-CHAVE: Surrealismo; Mito; Literatura; Iluminação Profana.

KEYWORDS: Surrealism; Myth; Literature; Profane Illumination. 


\section{INTRODUÇÃO}

Sabemos que boa parte das correntes vanguardistas do século XX se voltou ao primitivismo cultural, numa espécie de revisitação de culturas fundadoras dos povos primitivos de determinadas regiões do mundo, o que as levou ao encontro dos mitos desses povos que foram, em alguns casos, utilizados nas experimentações artísticas como forma de chocar o homem europeu preso a lógica capitalista e burguesa, oferecendo uma nova possibilidade de enxergar a vida, que é o caso do surrealismo, ou ainda como modo, de por meio do choque afirmar a cultura de determinadas nações e contribuir para a construção identitária de culturas colonizadas, como foi no Brasil, por exemplo, o caso da vanguarda antropofágica e de obras como Macunaíma (1928), de Mário de Andrade.

Esse artigo pretende debruçar-se sobre a relação entre mito e literatura na vanguarda surrealista, levando em consideração a ideia de que o surrealismo buscou em mitos de diversos povos uma maneira de oferecer ao homem daquele tempo uma apreensão outra da realidade, fugindo de pares de oposição e possibilitando uma visão expandida da vida na qual realidade e sonho fizessem parte do mesmo conjunto de coisas, o que poderia levar à revolução da existência, além disso, o surrealismo toma diversos mitos e os ressignifica, dando a eles uma nova camada de entendimentos, atualizando-os no contexto moderno, buscando, assim, criar uma

mitologia moderna, na qual os mitos fundadores dialogassem com o tempo presente e com aquilo que o surrealismo pretendia, que era mobilizar as energias para a transformação da vida e reencantar o mundo.

A ideia de revolução da existência e transformação da realidade está presente nos estudos de Walter Benjamin sobre o surrealismo e norteia o conceito de iluminação profana, uma espécie de epifania que traz ao homem o olhar político, capaz de questionar o mundo que vive e então lutar por sua modificação.

Por esse motivo, pretendemos abordar a questão da criação de uma mitologia moderna e da iluminação profana na literatura surrealista, a partir da observação de duas importantes obras dessa vanguarda, Nadja, livro de André Breton de 1928 e O camponês de Paris, obra de Louis Aragon do mesmo ano, para assim estabelecer algumas relações entre mito e literatura no surrealismo.

\section{O MITO E A ILUMINAÇÃO PROFANA NO SURREALISMO}

O movimento surrealista, considerado a última vanguarda europeia, começa a sua germinação aproximadamente em 1919, surgindo oficialmente em 1924 com a publicação do Manifesto do surrealismo, de André Breton. Esse movimento crítica a ordem dominante, os costumes capitalistas e burgueses, almejando ressignificar a vida humana, na tentativa de libertar o homem da "gaiola de aço,", termo trazido por Löwy
1. LÖWY. A estrela da manhã: surrealismo e marxismo, p. 9. 
2. BRETON. Manifestos do surrealismo, p. 40.

3. MICHELLI. As vanguardas artísticas, p. 152. a partir de Weber, em que estava encerrado por conta do processo civilizatório moderno e da constituição daquilo que Breton chamará no já citado manifesto de "império da lógica”.

O surrealismo pretendia "transformar o mundo" e "mudar a vida", de acordo com o que pregou respectivamente Marx e Rimbaud, a partir de uma produção artística que ligasse arte e vida, interior e exterior, imaginação e realidade, na tentativa de modificar um contexto marcado pela crise e pelo mal-estar do pós-guerra, por isso, viam a arte como objeto de ação e revolução, ela deveria estar intimamente ligada à vida e à construção de um mundo novo. Sendo assim, uma arte que não atendesse a esses ensejos não poderia ser de forma alguma levada a sério, uma vez que o destino do homem que estava em jogo.

O mote de Rimbaud, "a literatura é uma idiotice", também é a sua palavra de ordem: o que está em jogo é muito mais importante do que a arte de fazer quadros ou de escrever versos, está em jogo o destino do homem, seu sucesso ou sua ruína na Terra. É isso que o surrealismo entende e é justamente na direção dessa verdade sem subtendidos que tem início a sua ação. ${ }^{3}$

A capacidade revolucionária do surrealismo é o que encanta Walter Benjamin, que em seu texto intitulado "O surrealismo: o último instantâneo da inteligência europeia", de 1929, mostra o movimento como o único capaz de mobilizar para a revolução: "em todos os seus livros e iniciativas, a proposta do surrealismo tende ao mesmo fim: mobilizar para a revolução as energias da embriaguez". ${ }^{4}$

A ideia de Benjamin liga-se diretamente a preocupação surrealista trazida por Micheli na citação anterior, através da ideia de Rimbaud de que "a literatura é uma idiotice", na medida em que o movimento não levava em consideração a arte pela arte, ou seja, a arte com o fim em si mesma, mas pedia uma arte que fosse instrumento de choque, que se relacionasse intrinsecamente com a práxis vital e com a política, o que anunciaria uma explosão dentro da própria esfera da literatura, segundo Benjamin: "o domínio da literatura foi explodido de dentro, na medida em que um grupo homogêneo de homens levou a "vida literária" até os limites extremos do possível". ${ }^{5}$

Essa vanguarda que motivou parte das reflexões benjaminianas, influenciou muitos artistas ao redor do mundo e continua a ter grande força no tempo presente, afinal, "o estado de espírito surrealista, [...] o comportamento surrealista, é eterno" ${ }^{\text {e }}$ "está bem longe de ter dito suas últimas palavras", 7 buscou quebrar a lógica que sustentava o mundo capitalista e burguês, aproximando elementos aparentemente opostos como o sonho e a vigília, a realidade e a
4. BENJAMIN. O surrealismo: 0 último instantâneo da inteligência europeia, p. 32

5. BENJAMIN. O surrealismo: o último instantâneo da inteligência europeia, p. 22.

6. NADEAU. História do surrealismo, p. 9.

7. LÖWY. A estrela da manhâ: surrealismo e marxismo, p. 9 . 
imaginação, a consciência e a inconsciência, a racionalidade e a irracionalidade, vendo nesse modo expandido de ver a vida, uma maneira de revolucioná-la.

O homem procurado pelo surrealismo é o oposto daquele que a civilização moderna construiu, por meio da rejeição da subjetividade, do mitológico, da revolta, da utopia e pela valorização do conhecimento científico, da racionalidade, da lógica e do acúmulo do capital.

O surrealismo quer, então, encantar o mundo, que o processo moderno de civilização desencantou, por meio da recuperação do pensamento analógico, mitológico e subjetivo, quer, ainda, permitir que o homem encontre em seu interio e no próprio chão do cotidiano, o maravilhoso que pode transformar a sua vida e por isso dá tamanha importância aos mitos, buscando reconstruí-los no contexto da modernidade, de acordo com Michael Löwy:

O surrealismo [...] é [...] um movimento de revolta de espírito e uma tentativa eminentemente subversiva de re-encantamento do mundo, isto é, de reestabelecer, no coração da vida humana, os momentos 'encantados' apagados pela civilização burguesa: a poesia, a paixão, o amor-louco, a imaginação, a magia, o mito, o maravilhoso, o sonho, a revolta, a utopia $\mathrm{Ou}$, se assim o quisermos, um protesto contra a racionalidade limitada, o espírito mercantilista, a lógica mesquinha, o realismo rasteiro de nossa sociedade capitalista industrial, e a aspiração utópica e revolucionária de "mudar a vida". ${ }^{8}$

A valorização do pensamento mitológico é uma das formas de rebelar-se contra a lógica burguesa e de possibilitar ao homem a criação de outra relação com a vida, que não se determinaria mais por uma racionalidade voltada a fins práticos e que rejeitasse qualquer incursão pelo subjetivo e pelo insólito e é por isso que os surrealistas vão buscar em Friedrich Schlegel e em seu Discurso sobre a mitologia, publicado originalmente em 1800, um dos mais importantes textos do romantismo alemão, uma inspiração para tratar do mito revelando ao homem a capacidade de ter o encontro com o sagrado, com a magia em seu interior e nas banalidades da vida cotidiana, o que levaria a uma outra ordem de existência, indicando a possibilidade de transformação da realidade.

O mito moderno pretendido pelos surrealistas, além disso, oferecia-se como uma alternativa não religiosa no terreno da subjetividade, ele seria capaz de trazer a iluminação e/ou a revelação ao ser humano: "a atração dos surrealistas pelo mito deve-se também ao fato de constituir [...] uma alternativa profana ao domínio religioso sobre o universo do não racional".

Nesse sentido, encontramos inúmeras relações entre o conceito de iluminação profana, advinda dos estudos de
8. LÖWY. A estrela da manhã: surrealismo e marxismo, p. 9.

9. LÖWY; SAYRE. Revolta $e$ melancolia: o romantismo na contracorrente da modernidade, p. 201. 
Benjamin sobre o surrealismo e a ideia de construção de uma mitologia moderna que fosse uma alternativa profana à religião, de acordo com que vimos anteriormente com Löwy e Sayre. Para Walter Benjamin, a arte surrealista era capaz de causar em seu receptor uma espécie de epifania, uma revelação, uma iluminação, uma sensação de transcendência fora do universo religioso e por isso tratada como profana.

Essa iluminação profana indicaria a possibilidade de revolucionar a vida e a realidade, pois traria à tona a troca de olhares, uma vez que o olhar histórico, constituído pela alienação e passividade, tornaria-se olhar político, que observaria, por sua vez, os problemas ao seu redor de forma crítica e lutaria ativamente pela modificação desse estado de coisas. Benjamin dizia que os surrealistas foram os primeiros a perceber a força contida em imagens que poderiam levar a iluminação profana e então ao entendimento da degradação da vida humana diante dos adventos modernos, dos costumes burgueses e das imposições capitalistas:

Ele [o surrealismo] pode orgulhar-se de uma surpreendente descoberta. Foi o primeiro a ter pressentido as energias revolucionárias que transparecem no 'antiquado', nas primeiras construções de ferro, nas primeiras fábricas, nas primeiras fotografias, nos objetos que começam a extinguir-se, nos pianos de cauda, nas roupas de mais de cinco anos, nos locais mundanos, quando a moda começa a abandoná-los. Esses autores compreenderam melhor do que ninguém a relação entre esses objetos e a revolução. Antes desses videntes e intérpretes de sinais, ninguém havia percebido de que modo a miséria, não somente a social como a arquitetônica, a miséria dos interiores, as coisas escravizadas e escravizantes, transformavam-se em niilismo revolucionário. ${ }^{10}$

Vemos o poder presente em imagens que revelam oposições, por exemplo, o novo e o velho, o atual e o antiquado, um poder formado por uma ambiguidade que coloca em risco o padrão vigente. As novas técnicas modernas, as novas invenções punham abaixo antigos costumes e pediam um novo olhar para a realidade, além disso, traziam outras questões, como a da sedução humana diante do nunca visto, daquilo que era novidade e também do impacto diante do obsoleto, visto que no contexto moderno diversos objetos eram criados com bastante rapidez e com essa mesma velocidade tornavam-se ultrapassados.

A percepção dessa ambiguidade, segundo Benjamin, poderia trazer o olhar revolucionário, por isso mesmo que o estudioso vê emanar das páginas de Um camponês de Paris (1928) um "charme irresistível", 1 afinal de contas é o andar do sujeito - um flâneur - pelos destroços da passagem da Ópera que simbolizavam o caráter perturbador e ao mesmo tempo transformador presente nas ruínas trazidas em nome
10. BENJAMIN. O surrealismo: o último instantâneo da inteligência europeia, p. 25.
EM TESE
BELO HORIZONTE v. 22

N. 2

MAIO-AGO. 2016

ANDRADE. Mitologia moderna e iluminação profana: um breve passeio [...] P. 266-281

11. NASCIMENTO. Apresentação, p. 25. 
12. NASCIMENTO. Apresentação, p. 27.

13. PALMEIRA. Poeta, isto é revolucionário: itinerários de Benjamin Péret no Brasil, p. 117.

14. LÖWY; SAYRE. Revolta $e$ melancolia: o romantismo na contracorrente da modernidade, p. 202-203. do progresso, confirmando a ideia de Baudelaire que louvava no artista moderno "a sua capacidade de extrair o poético e eterno daquilo que é perecível e fugaz" ${ }^{12}$

Esses elementos revelavam a capacidade humana de encontrar encantos, poesia e mitologia em um simples passeio pelas ruas de uma grande cidade, o que era, em certa medida, a busca poética surrealista: "a poesia surrealista, que procura alçar os objetos diários à esfera lírica, rege-se pelo princí pio segundo o qual a imagem se grada à medida que são postas em relação palavras de naturezas distantes. Juntas, assumem, pela palavra do poeta, uma nova dimensão de significações". ${ }^{13}$

Essa nova dimensão de significações é capaz de criar mitologia, de trazer revelações e apreensões outras da existência, reencantando o mundo. A criação de uma nova mitologia em meio ao caos urbano podia certamente causar a iluminação profana benjaminiana e revolucionar a vida. A mítica surrealista evocava e ressignificava em tempos modernos "os mitos de Ísis e Osíris, o mito de Melusina, o mito da Salvação terrena pela mulher, o mito astrológico do arcano 17, o mito de Satã, Anjo da Liberdade, e, sobretudo, "um mito dos mais poderosos": o amor louco"14, além disso, valia-se, para a constituição desse mito novo, do "poder profético de certos videntes do passado - como Rimbaud, Nietzsche, Kierkegaard, Sade, Lautréamont -, ou do presente, como Ernst, cuja obra apresenta um caráter "mitológico" e "premonitório". ${ }^{15}$

Benjamin trata disso ao nos mostrar os autores surrealistas, como "videntes" e "intérprete de sinais", pois eles perceberam "de que modo a miséria, não somente a social como a arquitetônica, a miséria dos interiores, as coisas escravizadas e escravizantes, transformavam-se em niilismo revolucionário", ${ }^{16}$ ou ainda, de que forma a degradação humana, as ruínas causadas pela modernidade e a destruição tinham o poder de despertar para a revolução, uma vez que poderiam causar à iluminação profana.

Desse modo, notamos que para o surrealismo, a poesia e os poetas são capazes de adiantar acontecimentos, numa espécie de premonição, o que dá a palavra um poder de ritual, de vidência, de feitiçaria. É esse poder presente na poesia e do qual o poeta é dono que também compõe o novo mito que o surrealismo pretende criar, na medida em que a palavra como elemento de feitiço, tem a capacidade de revelar fatos e ainda transformá-los, o que indica o potencial da arte de mudar a realidade, o que faz do poeta o grande sábio, de acordo com o que diz Rimbaud.

Percebemos assim que muito daquilo que o surrealismo usará como inspiração para lidar com os mitos e propor a criação de uma nova mitologia advém do romantismo e da própria tradição artística, contudo o mito surrealista está em
15. LÖWY; SAYRE. Revolta e melancolia: o romantismo na contracorrente da modernidade, p. 202.

16. BENJAMIN. O surrealismo: o último instantâneo da inteligência europeia, p. 25.
EM TESE
BELO HORIZONTE
v. 22
N. 2 MAIO-AG0. 2016
ANDRADE. Mitologia moderna e iluminação profana: um breve passeio [ ...] . 266-281 
17. LÖWY; SAYRE. Revolta $e$ melancolia: o romantismo na contracorrente da modernidade, p. 203.

constante movimento, é um mito coletivo sempre incompleto e capaz de se criar e se formar a todo o momento: "sendo antes de tudo uma atividade do espírito, o surrealismo não pode se fixar em um "mito último", um graal a conquistar ou uma "surrealidade" reificada: o inacabamento perpétuo é seu elixir da imortalidade". ${ }^{17}$

\section{O CAMPONÊS DE PARIS E NADJA: O MITO E AS ILUMINAÇÕES PROFANAS NOS PASSEIOS ERRANTES SURREALISTAS}

O camponês de Paris, de Louis Aragon e Nadja, de André Breton são obras de 1928 e estão entre as mais importantes narrativas que o surrealismo produziu. Nelas podemos encontrar muitas das questões que nortearam o movimento, como, por exemplo: a escrita automática, o acaso objetivo, a deambulação surrealista e a criação de uma nova mitologia.

Os dois últimos elementos trazidos estão presente na composição de ambas as narrativas. A deambulação surrealista faz parte do projeto do movimento e foi uma experimentação muito comum entre os próprios surrealistas, ela relaciona-se ao passeio sem rumo pelas ruas da cidade, esse caminhar errante que podia propiciar o encontro com o maravilhoso e com acasos capazes de causar diversas reflexões, o que se relaciona diretamente à criação de uma mitologia moderna.

A deambulação do flâneur pela cidade pode ser pensada como uma das formas surrealistas de fugir da lógica capitalista e burguesa, representada por homens correndo apressados em busca de atender ao tempo do trabalho e à necessidade de ganhar dinheiro, o flâneur anda com calma, a espera de ser surpreendido e rejeita essa racionalidade determinada a fins, como podemos ver em Nadja, por meio do narrador, que recusa o trabalho, vendo-o como uma forma de não estar vivo, pois impede o encontro com o maravilhoso:

E não me venham, depois, falar de trabalho [...]. Que as sinistras obrigações da vida mo imponham, vá lá, mas que me peçam para acreditar nele, respeitar o meu ou o dos outros, jamais. Prefiro, de novo, caminhar na noite a me acreditar aquele que caminha no dia. De nada serve estarmos vivos durante o tempo em que trabalhamos. O evento que cada um de nós está no direito de esperar seja a revelação do sentido de sua própria vida, evento esse que talvez ainda não tenha encontrado, mas a caminho do qual eu sigo, não virá ao preço do trabalho. ${ }^{18}$

Aragon em $O$ camponês de Paris, especialmente no início da obra, no chamado "Prefácio para uma mitologia moderna" também chama atenção para a impossibilidade de homens que vivem "nos hábitos do mundo com uma comodidade crescente" ${ }^{19}$ de encontrarem o mito que está presente
18. BRETON. Nadja, p. 58.

19. ARAGON. $O$ camponês de Paris, p. 42. 
20. ARAGON. O camponês de Paris, p. 40. no cotidiano, uma vez que a lógica burguesa e capitalista impede o contato com o maravilhoso.

O "Prefácio para uma mitologia moderna" tece uma série de críticas ao racionalismo, ao cartesianismo e aos binarismos, pois esses empobrecem a relação do homem com a vida. A razão é, então, a própria "gaiola de aço" que os surrealistas buscam se livrar. Aragon nos mostra a incapacidade da razão em explicar tudo, revelando a importância de deixar os sentidos tomarem conta, libertando-se das imposições racionais, deixando o pensamento fluir: "pensar simplesmente como parece natural, conforme aquilo que vejo e toco", ${ }^{20}$ para que assim a imaginação tome o poder.

No entanto, ainda nesse prefácio, Aragon conclui que razão e a imaginação não podem ser tratadas separadamente, mostrando que essa separação é apenas funcional, já que razão e imaginação vivem lado a lado e por isso a busca por explicar tudo racionalmente, não consegue, muitas vezes, entender a essência dos fatos e a beleza por detrás deles:

[...] mesmo quando o mais sábio dos homens me tiverem ensinado que a luz é uma vibração, quando tiverem calculado para mim o comprimento de sua onda, seja qual for o fruto dos seus trabalhos racionais, ainda assim não terão dado conta daquilo que me importa na luz, daquele pouco que meus olhos aprendem dela, daquilo que me diferencia do cego e que é matéria para milagre e não objeto da razão. [...] Na verdade começo a experimentar em mim a consciência de que nem os sentidos, nem a razão podem [...] conceber-se separadamente, e que sem dúvida eles existem apenas funcionalmente. ${ }^{21}$

Desse modo, percebemos a necessidade da quebra de binarismos e ainda da aproximação de elementos que parecem opostos e distantes, como é o caso da imaginação e da razão. Isso faz parte daquilo que o surrealismo pretende, aproximar imagens distantes, acreditando na força poética existente nisso, de acordo com o que está já no primeiro manifesto do movimento:

A imagem é uma criação pura do espírito. Ela não pode nascer da comparação, mas da aproximação de duas realidades mais ou menos afastadas. Quanto mais as relações das duas realidades aproximadas forem longínquas e justas, mais a imagem será forte, mais força emotiva e realidade poética ela terá. ${ }^{22}$

A mítica surrealista baseia-se nessa aproximação, pois a força da imagem criada por realidades longínquas pode trazer ao homem uma nova apreensão da realidade, o que se relaciona com a ideia de criação de uma realidade expandida, liberada daquilo que se convencionou a chamar de real, ou ainda uma realidade absoluta formada pelos polos dos sonhos e da realidade, como nos traz Breton no manifesto de 1924: "acredito na resolução futura destes dois estados, tão contraditórios na
21. ARAGON. O camponês de Paris, p. $40-41$.

22. REVERDY apud BRETON.

Manifestos do surrealismo, p. 35. 
23. BRETON. Manifestos do surrealismo, p. 45

24. ARAGON. $O$ camponês de Paris, p. 42. aparência, o sonho e a realidade, numa espécie de realidade absoluta, de surrealidade, se assim se pode dizer" ${ }^{23}$

O homem que enxergar e observar a realidade a partir dessa expansão poderá reencantar o mundo, ressignificar a vida e fazer a revolução, podemos dizer, ainda, que o homem ao olhar tais imagens aproximadas poderá ter a epifania da iluminação profana, lançando então o olhar político ao seu espaço e seu tempo.

Essas ideias ligam-se diretamente a criação de uma mitologia moderna, pretendida pelos surrealistas e que é tratada por Aragon em $O$ camponês de Paris. O reconhecimento da mitologia, que nasce todos os dias pelas ruas da cidade e nos acontecimentos cotidianos, só poderia ser trazido à tona por meio desse olhar outro para a vida, que não se baseia unicamente na racionalidade como método para explicar as coisas, que não passeia unicamente pelos caminhos da lógica e do pragmatismo, mas que esteja aberto a viver as experiências que podem aparecer, percebendo os diálogos entre razão e imaginação, não se fechando em definições exatas sobre as coisas:

Mitos novos nascem a cada um de nossos passos. Lá onde o homem viveu começa a lenda, lá onde ele vive. [...] A cada di modifica-se o sentimento moderno da existência. Uma mitologia se tece e se desenlaça. É uma ciência da vida que pertence unicamente àqueles que não têm experiência dela. Uma ciência viva que se engendra e se suicida. ${ }^{24}$
Notamos que Aragon nos fala sobre uma ciência da vida, utiliza-se então da ideia de ciência, objetiva e racional, para logo depois ligá-la ao acaso e a inexperiência, na medida em que essa ciência da vida não necessita de experiência, de práti$\mathrm{ca}$, pois só pode pertencer àqueles que estão realmente abertos a viver, vendo tudo com novidade e encantamento e é por isso que ele mostra que uma ciência da vida no contexto da modernidade se engendra e se suicida com o passar dos tempos.

A noção dessa ciência da vida que se engendra e depois se suicida diz respeito às próprias fases da vida, da criança ao adulto, Aragon nos pergunta: "E quanto a mim - tenho já vinte e seis anos - mereceria ainda participar desse milagre? Terei ainda por muito tempo o sentimento do maravilhoso do cotidiano?”. ${ }^{25}$

A fase da infância é o período em que essa ciência da vida se produz, se realiza, pois a criança é o ser inexperiente que vê em cada detalhe da vida encantos, uma vez que ainda não foi engolida pelo primado da lógica e da razão, vivendo nos campos da imaginação, tendo liberdade para viver seus sonhos e fantasias no próprio cotidiano. A valorização da infância, fase da liberdade e da imaginação, é algo que está presente também no primeiro manifesto do surrealismo: "Se conservar alguma lucidez, não poderá senão recordar-se de sua infância, que lhe parecerá repleta de encantos, por mais massacrada que tenha sido com o desvelo dos ensinantes". ${ }^{26}$
25. ARAGON O camponês de Paris, p. 42.

26. BRETON. Manifestos do surrealismo, p. 33.
EM TESE
BELO HORIZONTE
v. 22
N. 2
MAIO-AGO. 2016
ANDRADE. Mitologia moderna e iluminação profana: um breve passeio [ ...] . 266-281 
27. ARAGON. O camponês de Paris, p. 42

28. ARAGON. O camponês de Paris, p. 42 .
Já a fase adulta é marcada como o período em que essa ciência da vida se suicida, na medida em que o adulto não pode mais ver tudo como uma novidade, já que seus olhos observam tudo de forma pragmática e racional, isso impossibilita o encontro com o mito e o maravilhoso no cotidiano, por isso a dúvida de Aragon: "Terei ainda por muito tempo o sentimento do maravilhoso do cotidiano?”. ${ }^{27} \mathrm{E}$ a sua conclusão de que o homem "que se desfaz progressivamente do gosto e da percepção do insólito" ${ }^{28}$ encontra-se em um caminho sem volta, que não corresponde sequer à vida.

A possibilidade de deambulação, de encontro com o mito e de recriação de diversas mitologias na modernidade só pode ser realizada por homens adultos que mantivessem em si, de alguma forma, um olhar de criança diante da vida, ou seja, um olhar capaz de ver encantos e magia no dia-a-dia, encantos esses que vão levá-lo a refletir sobre a própria realidade, aqui se encontra ainda a ideia de acaso objetivo tratada por Breton e recorrente em Nadja.

A imagem do acaso objetivo é composta também pela junção de conceitos opostos, que são conciliados, de um lado o acaso, algo incerto, imprevisível, do outro a objetividade, representada pela certeza e pela previsão. Breton busca tratar disso como uma possibilidade de reflexão sobre a realidade e entendimento da necessidade de modificá-la, por meio de encontros casuais do cotidiano, que ressignificassem a realidade e reencantassem a vida, ou ainda, uma forma de discutir a realidade valendo-se de um outro caminho que não o racional.

O princípio do acaso objetivo relaciona-se com a ideia da deambulação, com a figura do flâneur, aquele que quer recomeçar a vida magicamente a cada dia, e com o espaço cidade presente tanto em $O$ camponês de Paris quanto em Nadja. É nas ruas da cidade, particularmente Paris nessas duas obras, que o mito vai surgir e que o maravilhoso vai tomar o poder o encontro casual entre Breton e Nadja, na segunda obra marcam esses aspectos e reiteram a preocupação surrealista entre a ligação da arte com a vida, invertendo esses planos, segundo Willer:

Nadja [...] é inteiramente regida pelo acaso objetivo, embora a expressão só viesse a ser utilizada por Breton mais tarde. Tem especial importância pelo modo como funde gêneros e pela alta voltagem poética. É a transposição para a escrita da identificação surrealista entre arte e vida, invertendo a relação entre os dois planos. ${ }^{29}$

Em Nadja o plano da vida adentra as páginas do livro, por isso a inversão, pois ele trata de um fato que realmente aconteceu, o encontro de Breton com essa mulher misteriosa e extremamente interessante enquanto ele caminhava "pelas ruas ao
29. WILLER. Magia, poesia e realidade: $\mathrm{o}$ acaso objetivo em André Breton, p. 330 
30. WILLER. Magia, poesia e realidade: $\mathrm{O}$ acaso objetivo em André Breton, p. 331

31. BRETON. Nadja, p. 60.

32. Cf.: WILLER. Magia, poesia e realidade: o acaso objetivo em André Breton.

33. ALMEIDA. A esfinge e a fragmentação da identidade em Nadja, de André Breton, p. 11.

34. BRETON. Nadja, p. 11.

saber do mesmo vento do eventual" ${ }^{30} \mathrm{O}$ encontro com Nadja revela-se como fruto da deambulação, resultado do acaso:

Observava, sem querer, as expressões, os andares, os adornos. Ora, não seriam ainda estes os capazes de fazer a Revolução. Tinha acabado de atravessar esse cruzamento cujo nome sempre me esqueço ou ignoro, ali diante da igreja. De repente, a cerca de uns dez passos de mim, vindo no sentido oposto, vejo uma jovem pobremente vestida, que também me vê, ou já me vira. Caminhara de cabeça erguida, contrariamente a todos os passantes. A criatura é tão frágil que mal toca o solo ao pisar. Um sorriso imperceptível era talvez em seu rosto. Curiosamente maquiada como alguém que, começando pelos olhos, não tivesse tempo de chegar ao fim, deixando o contorno demasiadamente negro para a sua compleição de loura. ${ }^{3}$

Nadja representa temas muito caros aos surrealistas, como a loucura, a liberdade, a errância, o desejo e, além disso, captava singularidades da vida antecipando acontecimentos. ${ }^{32} \mathrm{~A}$ mulher foi uma figura bastante importante para essa vanguarda, por ser a representante "da nova mensagem de liberdade que pretendem anunciar, contrariando uma sociedade que condena e reprime demasiadamente as aspirações femininas" ${ }^{33}$ não é á toa que ela encanta tanto o narrador da obra e o ajuda a refletir sobre a questão que abre o livro "quem sou?". ${ }^{44}$ lidade do surrealismo. Não só pela comprovação do inconsciente como fonte de imagens, mas por estas interferirem no presente ou preferem o futuro. Ambos trafegam por um território crepuscular onde realidade e sonho, um mundo sólido, estável, e outro volátil, da imaginação desencadeada se confundiam. ${ }^{36}$
36. WILLER. Magia, poesia e realidade: o acaso objetivo em André Breton, p. 334. 
É essa personagem, colocada da realidade para dentro do livro, que terá o poder de dar à cidade, misticismo, de recheá-la de insólito e de sobrenatural, como ocorre no episódio da praça Dauphine. Com Nadja a imaginação e o insólito pulam das páginas da ficção, invadindo a realidade, e dessa forma, o surrealismo nos mostra a possibilidade de encontrar o maravilhoso no cotidiano e ela revela isso a Breton, por meio de suas divagações e impressões sobre os espaços que percorrem em Paris.

A praça Dauphine é de fato um dos lugares mais profundamente retirados que conheço. [...] Nadja começa a olhar em redor. Está certa que sob nossos pés passa um subterrâneo que vem do Palácio da Justiça e contorna o Hotel Henrique IV. Perturba-se diante do que já aconteceu naquela praça e do que ainda ali ocorrerá. Onde a esta hora não se vêem mais que dois ou três casais perdidos, ela parece ver uma multidão. " $E$ os mortos, os mortos!" [...] Nadja agora percorre com olhar a fachada das casas. "Está vendo, lá em cima, aquela janela? Está às escuras, como as outras. Daqui a um minuto vai acender-se. Vai ficar inteiramente rubra." Passa-se um minuto a janela acende. Há, de fato, cortinas vermelhas. [...] Confesso que a essa altura o medo apossou-se de mim, e começou também a apossar-se de Nadja. "Que horror! Está vendo o que acontece com as árvores? $\mathrm{O}$ azul e o vento, o vento azul. [...] Lembro-me também uma voz que dizia: você vai morrer, vai morrer..
Eu não queria morrer, mas sofria tal vertigem. Teria caído da janela se alguém não me tivesse amparado" ${ }^{37}$

Vemos assim que a mulher no surrealismo pode ser a própria esfinge grega do mito de Édipo, só que ressignificada e dessacralizada, apontando um novo modo de conceber a vida e negando a ideia de que o homem está preso a um destino, do qual é impossível a fuga, algo que existe em Édipo e é negado pelo surrealismo, uma vez que para os surrealistas é o homem que define seu destino por seus desejos, não estando condicionado, portanto, a nada. A figura da esfinge é então reinventada no chão da modernidade e assim se abre o caminho para a decifração dos dilemas humanos:

A esse embate, Breton e o surrealismo, no rastro da perspectiva aberta por Freud, trazem outro aspecto, e propõem a consideração do desejo humano, mostrando que o destino do homem é definido justamente pelos seus anseios e por aquilo que lhe advém. Esses artistas modernos se dedicam a enfatizar a existência de uma realidade interior e psíquica que define as sensações pessoais, mas que era frequentemente ignorada por seus contemporâneos. [...] Não seria, portanto, o caminho da razão ou o da fé incondicional e submissa que colocaria o homem em contato consigo mesmo. A crítica do surrealismo aos mitos gregos se estende, então, à concepção de mundo que transparece através deles e que acaba por afastar ainda mais o homem de si mesmo. ${ }^{38}$ 
39. ARAGON. O camponês de Paris, p. 44 .

40. ARAGON. O camponês de Paris, p. 44.
É interessante notar que a esfinge também está presente em $O$ camponês de Paris, mas sendo representada não pela mulher, mas pela cidade, que aqui assume o poder do feminino. O corpo da mulher torna-se as ruas e vielas da cidade, as quais o poeta percorre de maneira sedutora, buscando sempre o lugar mais ermo, mais marginal e de difícil acesso, para assim chegar ao prazer pelos caminhos menos óbvios possíveis. A esfinge de Aragon são as passagens parisienses, a sua força de serem espaços "receptadores do mito moderno". ${ }^{39} \mathrm{E}$, além disso, espaços que também ressignificam, assim como faz Breton em Nadja, a questão mitológica no contexto da modernidade:

[...] nossas cidades são assim povoadas por esfinges desconhecidas que não detêm o passante sonhador se ele não volta para elas sua distração meditativa, esfinges que não lhe colocam questões mortais. Mas, caso ele saiba adivinhá-las, então este sábio que as interroga irá sondar ainda, novamente, seus próprios abismos graças a esses monstros sem rosto. A luz moderna do insólito: eis o que doravante irá retê-lo. ${ }^{40}$

As esfinges de O camponês de Paris não colocam ao homem questões mortais, mas o permite reconhecer seus próprios abismos, sua interioridade, caso esse esteja aberto sabiamente para esse encontro com elas, pois ele precisa reconhecer a força que emana delas, adivinhar o seu potencial perturbador e ao mesmo tempo revelador, que é o que faz Breton ao ver Nadja, a alma errante, como ela própria se define.

Dessa forma, notamos o modo como o surrealismo perseguiu a questão do mito, buscando mais do que usá-la na sua construção poética, mas ainda ressignificá-la para os tempos nos quais viviam, o uso do mito, para eles, era uma importante forma de recriar um imaginário e de possibilitar ao homem a percepção das forças reveladoras e transformadoras presentes em seu cotidiano.

Nadja e O camponês de Paris ilustram essa necessidade surrealista de atacar no campo do mito, recusando-se a abandoná-los aos "mitômanos fascistas" ${ }^{41}$ e percebendo a possibilidade do mito fundar um novo tempo e destruir as oposições nocivas à compreensão da vida.

A questão da criação da mitologia moderna relaciona-se com a questão da iluminação profana de Benjamin, na medida em que ambas as ideias remetem a um olhar outro para a realidade e à possibilidade da revolução em um tempo de barbárie criado ao longo do processo civilizatório moderno, tratando ainda do surgimento de um indivíduo que não vai seguir o fluxo que o rodeia de maneira alienada, mas que vai se opor a esse estado de coisas, mobilizado em transformá-lo.

Tanto em Nadja quanto em O camponês de Paris a mitologia moderna e a iluminação profana de Benjamin dialogam
EM TESE
BELO HORIZONTE
v. 22
N. 2
MAIO-AGO. 2016
ANDRADE. Mitologia moderna e iluminação profana: um breve passeio [...] . 266-281

41. LÖWY. A estrela da manhã: surrealismo e marxismo, p. 25. 
a todo momento, afinal o choque do contato com essas esfinges modernas traz à tona uma epifania que permite uma nova apreensão da vida. Breton ao se relacionar com Nadja procura entender-se e, mais que isso, percebe a possibilidade de se encontrar com o maravilhoso pelas ruas da cidade, enquanto o flâneur de Aragon sente o poder revolucionário e perturbador do passeio pela Passagem da Ópera o que revela novas significações da existência, ao exibir ao homem dilemas e reflexões.

Vemos que a deambulação pelas passagens parisienses ou aquela que leva ao encontro com Nadja são propiciadoras de iluminações, que profanam o sentido religioso da palavra, e é assim que surrealismo busca e encontra a transcendência libertando o homem da mitologia religiosa, mostrando a possibilidade do transcendente, do mítico e do maravilhoso fora do campo da religião e dentro do próprio homem e de seu cotidiano.

\section{CONSIDERAÇÕES FINAIS}

Notamos que os mitos foram bastante importantes para as experimentações surrealistas, por isso, Louis Aragon dedica a primeira parte do seu livro à criação de um prefácio intitulado: "Prefácio para uma mitologia moderna", no qual o autor critica o racionalismo, o cartesianismo, os binarismos e propõe uma forma expandida do homem ver a vida, o que possibilitaria o encontro com o maravilhoso e com o mitológico no chão do cotidiano e que André Breton escreve sobre Nadja, uma espécie de esfinge moderna, que o fascina, revelando a força poética do deambular pela cidade.

O surrealismo recupera boa parte das questões relacionadas ao mito que estiveram no bojo do romantismo e de outros momentos históricos, mas as transforma no contexto moderno, na tentativa de criar uma mitologia na modernidade, ressignificando o próprio mundo mítico e o aproximando do homem e do seu cotidiano. Para os surrealistas, a esfinge está na própria cidade e o mito brota nas ruas e vielas dos espaços urbanos, sendo assim, o mito deixa de ser algo que se relaciona unicamente com o universo da imaginação e adentra o contexto da realidade, fazendo com que esses dois opostos se conversem e muitas vezes se complementem.

No surrealismo o terreno dos mitos foi, como já dissemos ao longo do texto, uma maneira fundamental de adentrar o campo do não racional, oferecendo uma alternativa de transcendência e revelação fora do âmbito religioso, dando ao homem a capacidade de transcender e conquistar a iluminação na própria vida, o que se ligaria a ideia de iluminação profana, trazida por Walter Benjamin.

Neste sentido, mitologia moderna e iluminação profana tornam-se instâncias que dialogam. A ideia iluminação 
42. LÖWY. A estrela da manhã: surrealismo e marxismo, p. 46. profana criada por Walter Benjamin ao olhar a arte surrealista, vendo nela o potencial de "despertar as energias da embriaguez" e revolucionar a vida, uma vez que traria o olhar político, aquele que é capaz de criticar e mudar o mundo que o rodeia, está ligada à criação da mitologia moderna, que, por sua vez, oferece uma visão ampla da vida, sem se valer de binarismos ou do pensamento racional por si só.

O homem detentor desse olhar político teria uma visão expandida de sua realidade, não a enxergando por meio da lógica vigente e dos costumes padrões, mas, pelo contrário, fugindo disso tudo e estabelecendo uma relação diferente com o mundo. A iluminação profana oferece-se, assim, como uma possibilidade de transcendência também fora do âmbito religioso e acende no homem a necessidade de se liberta da "gaiola de aço", por meio do reencontro com o mundo dos mitos e do maravilhoso no seu próprio cotidiano.

Löwy (2002) nos fala que a ideia de embriaguez em Benjamin diz respeito à relação do homem dos primórdios com o cosmos, baseada no ritual e na magia, algo que desaparece ao longo da ascensão da sociedade moderna. Para Benjamin os surrealistas eram os únicos capazes de trazer essa relação de volta, não da mesma forma dos tempos antigos, mas por meio da iluminação profana, que se referia a "[...] um desvio pelo passado em direção a um futuro novo integrando todas as conquistas da modernidade". ${ }^{42}$
Sendo assim, toda a criação de uma mítica moderna no surrealismo está intimamente ligada ao princípio da iluminação profana, uma vez que o retorno ao mundo dos mitos, para transformá-los no contexto moderno passaria por essa epifania transformadora do modo de ver as coisas, por esse motivo Benjamin se encanta com $O$ camponês de Paris, já que via emanar de suas páginas a epifania, a transcendência e as iluminações.

Por fim, é possível dizer que a relação entre mito e literatura no surrealismo é bastante evidente, especialmente, quando observamos as obras escolhidas para essa breve leitura, no caso Nadja e O camponês de Paris, pois elas ilustram toda a tentativa surrealista de criar mitos modernos capazes de revolucionar a vida, por isso, é possível dizer que na poética surrealista a questão mítica liga-se à política e à revolução, já que é por meio dela que se poderá alcançar a transformação da sociedade, o que reitera novamente a fala de Walter Benjamin a partir do ideário em torno da iluminação profana.

\section{REFERÊNCIAS}

ALMEIDA, Danielle Grace de. A esfinge e a fragmentação da identidade em Nadja, de André Breton. Non plus literatura, São Paulo, v. 1, n. 1, p. 4-16, 2012

ARAGON, Louis. O camponês de Paris. Tradução de Flávia Nascimento. Rio de Janeiro: Imago, 1996. 
BENJAMIN, Walter. O surrealismo: o último instantâneo da inteligência europeia. In: BENJAMIN, Walter: Magia e técnica arte e política. Tradução de Sérgio Paulo Rouanet. São Paulo: Brasiliense, 1987, p. 21-35.

BRETON, André. Manifestos do surrealismo. Tradução de Sérgio Pachá. Rio de Janeiro: Nau Editora, 2001.

BRETON, André. Nadja. Tradução de Ivo Barroso. Rio de Janeiro: Imago, 1999.

LÖWY, Michael. A estrela da manhã: surrealismo e marxismo. Tradução de Eliana Aguiar. Rio de Janeiro: Civilização brasileira 2002

LÖWY, Michael; SAYRE, Robert. Revolta e melancolia: o

romantismo na contracorrente da modernidade. Tradução de

Nair Fonseca. São Paulo: Boitempo, 2015.

MICHELLI, Mario de. As vanguardas artísticas. Tradução de Pier Luigi Cabra. São Paulo: Martins Fontes, 2004.

NADEAU, Maurice. História do surrealismo. Tradução de Geraldo Gerson de Souza. São Paulo: Perspectiva, 1985.

NASCIMENTO, Flávia. Apresentação. In: ARAGON, Louis. 0 camponês de Paris. Tradução de Flávia Nascimento. Rio de Janeiro, Imago, 1996, p. 11-35

\section{PALMEIRA, Maria Rita Sigaud Soares. Poeta, isto é}

revolucionário: itinerários de Benjamin Perét no Brasil. 2000.

Dissertação (Mestrado em Teoria Literária) - Instituto de Estudos

da Linguagem da Universidade Estadual de Campinas, 2010.
SCHLEGEL, Friedrich. Discurso sobre a mitologia. In: SCHLEGEL, Friedrich. Conversa sobre poesia e outros fragmentos. Tradução de Victor-Pierre Stirnimann. São Paulo: lluminuras, 1994.

WILLER, Cláudio. Magia, poesia e realidade: o acaso objetivo em André Breton. In: GUINSBURG, Jacob; LEIRNER, Sheila (Org.). $\mathbf{O}$ surrealismo. São Paulo: Perspectiva, 2008, p. 323-350. 